\title{
Application of the Balance Scorecard as a Performance Measurement Instrument
}

\section{Diana Rapitasari ${ }^{1}$ \\ Ika Kharismawati ${ }^{2}$ Darwin Abd. Razak ${ }^{3}$}

${ }^{1,2}$ Faculty of Economics, Bhayangkara Surabaya University, Indonesia

Email:diana@ubhara.ac.id Tel: +62818315993

EEmail:Ika.rahmas6@gmail.com Tel:+6281393344038

Faculty of Social and Political Science University of Muhammadiyah North Maluku, Indonesia

${ }^{3}$ Email: radjak_bila20@yahoo.co.id Tel:+6282234834872

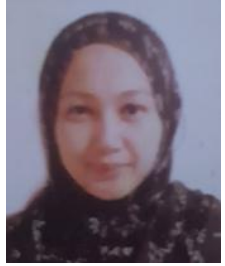

( Corresponding Author)

\begin{abstract}
The concept of the Balanced Scorecard develops in line with the development of the organization. The Balanced Scorecard consists of two words: (1) scorecard and (2) balanced. In the initial stages of the experiment, the Balanced Scorecard is a scorecard that is used to score the results of executive performance. Through a scorecard, the scores the executive wants to realize in the future are compared to actual performance results. The results of this comparison are used to evaluate executive performance. The word balanced is intended to show that executive performance is measured equally from two perspectives: financial and non-financial, short-term and long-term, internal and external. Because executives will be assessed for their performance based on score cards that are formulated in a balanced manner, executives are expected to focus their attention and effort on measures of non-financial performance and long-term measures (Mulyadi, 2007). In subsequent developments, the Balanced Scorecard is not only related to the cards used to record executive scores. The results of the study in year 1 were that the implementation of the BSC in the BKKBN began in 2007 and until now has improved many improvements. BSC which was initially only applied to Echelon II levels, in 2009 was applied to echelon III and IV levels, then it has also been applied at the staff level. The implementation of the $\mathrm{BSC}$ in the BKKBN is approved to have many benefits, including providing organizational communication strategies from the highest to the lowest level, providing a measure of target for increasing employee budgets, providing feedback to improve performance, and increasing commitment to support and improve performance.
\end{abstract}

Keywords: Implementation, Balance scorecard, Instrument, Measurement, Performance.

Citation | Diana Rapitasari; Ika Kharismawati; Darwin Abd. Razak (2018). Application of the Balance Scorecard as a Performance Measurement Instrument. Growth, 5(1): 13-16. History:

Received: 12 October 2018

Revised: 15 November 2018

Accepted: 20 December 2018

Published: 8 January 2019

Licensed: This work is licensed under a Creative Commons

Attribution 3.0 License (c) EY

Publisher: Asian Online Journal Publishing Group
Contribution/Acknowledgement: All authors contributed to the conception and design of the study.

Funding: This research was funded by the Directorate of Research and Community Service Directorate General of Strengthening Research and Development at the Ministry of Research, Technology and Higher Education. In accordance with the 2018 Fiscal Year Research contract No. 009/SP2H/LT/K7/KM/2018

Competing Interests: The authors declare that they have no conflict of interests.

Trans. The authors confirm that the manuscipt is an ho Transparency: The authors confirm that the manuscript is an honest,
accurate, and transparent account of the study was reported; that no vital features of the study have been omitted; and that any discrepancies from the study as planned have been explained.

Ethical: This study follows all ethical practices during writing.

\section{Contents}

1. Introduction

2. Research Methods

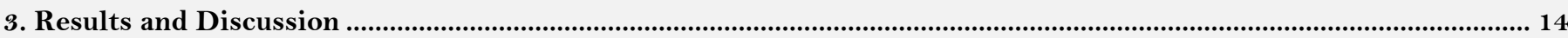

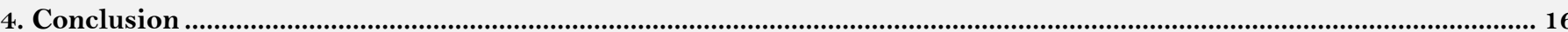

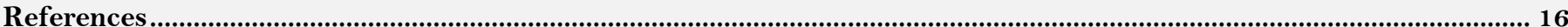




\section{Introduction}

From the very beginning it is important to understand why measuring organizational performance is very important and vital. An organization that operates without a performance measurement system, such as an airplane that flies without a compass, an F1 driver who drives and his eyes are closed.

The purpose of performance measurement is not only aimed at knowing how a business will perform but being able to create better performance. The main purpose of implementing a performance measurement system is to improve organizational performance so that it can better serve customers, employees, owners, and stakeholders. Where, the results of good performance measurement will be information on how the business is and how it is done, and where it occurs.

So far, performance measurement has only been done traditionally, namely by focusing on the financial side. Leaders who succeed in achieving a high level of profit will be considered successful and get good rewards from the organization. Organizational performance evaluation that is solely from the financial side will be misleading, because good financial performance can now be achieved at the expense of the organization's long-term interests. And conversely, poor financial performance in the short term can occur because the organization makes investments in the long term interest.

Performance measurement in management control systems in an organization occupies a very important position as an effort to map strategies into actions to achieve certain targets. This performance measurement system is often used as an organizational control tool, because it is strengthened by establishing a system of reward and punishment (Ulum, 2009).

To overcome the problem of weaknesses in measuring organizational performance systems focusing on financial aspects and ignoring non-financial performance, such as customer satisfaction, employee productivity, and so on, a performance measurement model is created that does not only cover finance but non-finance, namely the Balanced Scorecard concept (BSC).

The concept of the Balanced Scorecard becomes a means to communicate strategic perceptions in an organization in a simple and easy way to be understood by various parties in the organization, especially those in the organization who will formulate the organization's strategy. The definition of the Balanced Scorecard itself if translated can be meaningful as a balanced report card performance (Balanced). A scorecard is a card that is used to record scores on the performance results of a person and / or a group, also to record the score plan that is intended to be realized.

Measurement of performance with the Balanced Scorecard is not only limited to business organizations, but also to public organizations. The difference between the two can be seen from the objectives and stakeholders. The application of the Balanced Scorecard in the business sector is intended to increase competition (competitiveness), while the public sector emphasizes mission, value, effectiveness. While from the financial aspect, the business sector will prioritize profits, growth and market share while the public sector is intended to measure productivity and efficiency. Likewise with the parties concerned, the business sector will prioritize shareholders, buyers and management, while for the public sector includes taxpayers, service users and legislation (Imelda and Zubair, $2004)$.

\section{Research Methods}

\subsection{Research Design}

Identification of factors that influence organizational performance through the application of a balanced scorecard in Sidoarjo Regency, determinants of the factors that influence the success of implementing the balance scorecard as an organizational performance measurement instrument in Sidoarjo Regency. The design of this study used research models such as participant action research, action research diagnosis and empirical action research (Kemmis and Taggart, 1990).

\subsection{Research Sites}

This research was carried out in the East Java BKKBN, at Public Institutions because this agency had implemented a balance scorecard method and had succeeded in maintaining program achievements despite being faced with situations and conditions that were no longer the same as the New Order era.

\subsection{Data Collection Techniques}

The technique used to collect data is by in-depth interviews, observation and documentation.

\subsection{Resources}

In determining the information source to explore data in the need assessment, the public servants are directly related to the performance assessment process.

\subsection{Data Analysis Technique}

The data analysis technique of this research is descriptive qualitative. In descriptive research, the process of analyzing and interpreting data is not only done at the end of data collection or on its own, but simultaneously is also done at the time of field data collection takes place, so that qualitative research is often known as a cycle process.

\section{Results and Discussion}

\section{Implementation of the Balanced Scorecard in the Central BKKBN}

The application of the Balance Scorecard at the Central BKKBN was initially in the background of efforts to reform the bureaucracy as a form of elaboration of Presidential Instruction number 7 of 1999 concerning the performance accountability of government agencies. This Presidential Instruction is a breakthrough in an effort to create a professional, efficient and effective state administration system especially for government organizations to 
improve their performance and encourage the development of performance-based management systems in public sector organizations.

The BSC is theoretically able to improve organizational communication through the elaboration of organizational strategies in the form of strategic goals, sizes and targets from the highest organizational level to the lowest organizational level. In the performance management cycle there are generally 3 stages that must be passed namely Employee Performance Planning, Monitoring Employee Performance, and Employee Performance Assessment. To plan employee performance targets, it is necessary to know the performance targets of the bureau in advance, which are derived from the performance targets of the organization / ministry that are poured into the vision, mission, and mapped onto the strategy map. At the stage of employee performance planning, employee performance targets are determined for the next year and poured into a form called Employee Performance Assessment (PKP). The second stage is monitoring employee performance. In achieving performance targets, employees sometimes need to be given feedback, coaching \& counseling, or disciplinary actions in accordance with applicable rules and regulations. In the third stage, the performance targets set at the beginning will be evaluated periodically every quarter, and then will be assessed along with the competency aspects of the employee itself each semester. The results of this assessment determine the provision of compensation in accordance with the performance of employees, both in the form of bonuses, promotions, or other programs. At this stage, it is also agreed on what development programs are needed by these employees.

BKKBN BSC is a method used to translate Strategic Plan and BKKBN Road Map into strategies which are then described in the form of a strategy map to facilitate the reduction of the strategy from the highest level to the lowest level. The BKKBN road-map in this case is the elaboration of the BKKBN Strategic Plan in more detail which contains BKKBN programs and activities in general within a period of 5 years. Thus the BSC can be used as a tool that produces feedback to revise the Strategic Plan.

In his presentation on the application of the BSC in the BKKBN for performance management, the Head of the Central BKKBN Planning Bureau explained step by step the development of the BSC in the BKKBN as follows.Dalampemaparantentangpenerapan BSC di BKKBN untukmanajemen

\section{Compilation of Strategy Maps}

a. Make Organizational Vision and Mission

The BKKBN BSC preparation phase starts with creating a vision and mission. Vision and Mission are made by analyzing the strengths, weaknesses, opportunities and threats contained in the organization. Such analysis can be carried out using the SWOT or PEST analysis method. From the analysis and assessment of the organization, it can be seen what is the vision and mission of the organization, strengths and weaknesses, even what actions must be taken by the organization to meet the needs of the community.

b. Determine the perspective of the strategy map

The strategic map in the BSC generally consists of 4 (four) perspectives namely

1) Stakeholders and customers are parties who have an interest in the outcome of an organization.

2) Internal Business Process, which shows a series of processes in a unit to create value for stakeholders and customers (value chain);

3) Learning and Growth, namely activities to improve the ability of employees to support the achievement of 3 (three) previous perspectives.

4) Financial that describes the financial success achieved by the organization for the activities carried out.

In BKKBN all four perspectives are used, but with adjustments related to the orientation of the goals and objectives of the establishment of this Agency

c. Determine key objectives of the organization's vision and mission

In this case a direct example is used in the BKKBN. It is known that the BKKBN Vision is a Balanced Growing Population 2015 and with the mission of Realizing a Population-Based Development and a Happy Family of Prosperous Families. The bottom line in a few sentences in BKKBN's vision and mission is the key words that will be elaborated in the form of strategic goals.

d. Translating Keywords Into Strategic Goals

After the Vision and Mission are known, the next step is to determine the ideal and realistic conditions to be achieved by BKKBN through the description of the keywords of the vision and mission above into a number of Strategic Objectives (SO). The following is the Strategic Objective (SO) as a description of the keywords of the BKKBN's vision and mission.

BKKBN Customer and Stakeholder Perspectives

1) Increased Knowledge, Attitudes and Behavior of the Community in Population Development and Family Planning;

2) Increased Stakeholder commitment to Population Development and Family Planning;

3) Increased role of work partners in population development and family planning.

BKKBN Internal Business Process Perspective

1) Enhancing partnerships in population and KB development;

2) Increasing Advocacy, Mobilizing and Imaging Stakeholders;

3) Improve Population Development and Family Planning communication, information and education;

4) Increase the guarantee of availability of facilities and infrastructure for Population Development and Family Planning;

5) Matching Population Development and Family Planning policies;

6) Ensure the availability of utilization of population parameters and population impact assessment information data;

7) Improve IT-based SIM; 
8) Increasing Population Development and R \& D and KB;

9) Improving Good Governance.

BKKBN Learning and Growth Perspective

1) Planning and Developing HR;

2) Organizing organization and management;

3) Developing a CUK work culture.

\section{Conclusion}

The Balance Scorecard implementation at BKKBN began in 2007 and until now has undergone many improvements. The Balance Scorecard, which was initially only applied to Echelon II levels, in 2009 was applied to echelon III and IV levels, then it has also been applied to staff levels in 2010. The Balace Scorecard implementation at the BKKBN is considered to have many benefits including being able to communicate organizational strategy from the highest to the lowest level, provides objective measures of employee performance appraisal, provides feedback to improve performance, and increases leadership commitment to evaluate and improve performance.

However, even though it has been implemented for several years, the obstacles to implementing the Balance Scorecard at BKKBN are still found here and there. Some of the problems that can be identified are the Development of the Balance Scorecard in several work units running backwards, lack of knowledge of employees on the implementation of the Balance Scorecard system at BKKBN, cascading processes that are not fully implemented, Flexibility in giving assessment weights, and lack of information technology support in implementing the Balance Scorecard at BKKBN.

\section{References}

Imelda, A. and M. Zubair, 2004. Community-based disaster risk management: Field practitioners' handbook. Bangkok: Asian Disaster Preparedness Center (ADPC).

Kemmis, S. and R.M. Taggart, 1990. The action research planner. Melbourne: Deakin University.

Mulyadi, 2007. Balanced scorecard: Contemporary management tool for multiplying corporate financial performance. 5th Edn., Jakarta: Salemba Empat.

Ulum, I., 2009. Intellectual capital: Concept and empirical study. Yogyakarta: Graha Ilmu. 